\title{
Mashanov M.A. and His Contribution to the Studies of the History and Ethnography of Turkic and Finno-Ugric Peoples of the Middle Volga Region and Cisural Area (1852-1924)
}

\author{
Ramil M. Valeev ${ }^{1}$, Mars Z. Khabibullin ${ }^{1}$ \& Guzel Z. Khabibullina ${ }^{1}$ \\ ${ }^{1}$ Kazan (Volga Region) Federal University, Kazan, Russia \\ Correspondence: Ramil M. Valeev, Kazan (Volga Region) Federal University, 420008, Kazan, Kremlyovskaya \\ Street 18, Russia. E-mail: valeev200655@mail.ru; ram.valeev2016@yandex.ru
}

Received: June 2, 2015 Accepted: June 15, 2015 Online Published: June 29, 2015

doi:10.5539/jsd.v8n5p197

URL: http://dx.doi.org/10.5539/jsd.v8n5p197

\begin{abstract}
The issues of inter-ethnic and inter-confessional relations have always attracted the attention of researchers. The given paper is aimed at studying the life and activity of a missionary, a scientist and a lecturer of the missionary anti-Muslim department of the Kazan Theological Academy Mikhail Aleksandrovich Mashanov; his contribution to the investigation of the history, ethnography, language and culture of the Turkic and Finno-Ugric peoples of the Middle Volga region and Cisural area in the second half of the $19^{\text {th }}$ and at the beginning of the $20^{\text {th }}$ centuries; the examination and development of the problems of Islam and Christianity in Russia and Middle East. The authors explored the missionary and social activity of Mashanov who played an important role in the process of Christianization and Russification of the non-Russian peoples in the Volga region and Cisural area. The research reviews the scientist's contribution to the education of the Tatars, Chuvash, Maris, Udmurts and Mordvins as members of the orthodox organization, the Brotherhood of St. Gurias; analyzes the scientific works and Mashanov's contribution to historico-confessional and ethno-political study of the Turkic and Finno-Ugric peoples of Russia and the Republic of Tatarstan in the second part of the $19^{\text {th }}$ and the beginning of the $20^{\text {th }}$ centuries, the preservation and development of the languages, the formation of national education. The authors managed to find out and collect a huge number of various (historical, linguistic, ethnographic) materials about the Tatars, Maris, Chuvash, Udmurts, Mordvins, which are of great importance while investigating the roots of modern international and inter-confessional relations in the Republic of Tatarstan and the Russian Federation. The paper findings may be useful for researches who deal with the missionary policy and modern ethno-political processes in the Russian Federation.
\end{abstract}

Keywords: M.A.Mashanov, the missionary anti-Muslim department of the Kazan Theological Academy, people of the Middle Volga region and Cisural area, Ethnography, History, Islam, Christianity

\section{Introduction}

In Russia, the last decades of the century saw the development of national and confessional components in regions and subjects of the Federation. The topics of current interest are to improve professional competence in dealing with interreligious encounter and international conflicts, eliminating interethnic intensity. Thus, the humanities, including researches on ethnic variations and backgrounds, national structures and relations, acquire steadily increasing significance. Studies of the history, ethnography, cultural heritage and languages of the peoples and nationalities of Russia have been of important theoretical and practical value.

The collaboration of adherents of Islam and Christianity has been notably maintained in the Middle Volga region. It is just here, after the fall of the large Turkic state of the Kazan Khanate in 1552, the Russian government carried out extensive missionary activities in relation to Turkic, Finno-Ugric and Mongolian ethnic groups and the people of the Volga region and Cisural area. The main purpose was renunciation of Islam, forced Christianization, Russification, the creation of a specific educational system and institutions and also the establishment of special missionary orthodox organizations. Many Russian scientists devoted their works to the educational and missionary policy of the Russian state in relation to the people of the Volga region, among which it is necessary to point out Valeev R.M. (1998), Islayev F.G. (1999), Dimitriyev V.D. (2002), Taymasov L.A. (2004) and western experts such as Bennigsen A. (1967), Pipes R. (1993), Uyert P. (1997), Geraci R. (2001), and 
others.

In the second part of the $19^{\text {th }}$ and at the beginning of the $20^{\text {th }}$ centuries the Kazan Theological Academy was a powerful religious, scientific and educational institution, the centre of maintaining the extensive missionary policy in Russia, the provider of the Russian policy on Christianization and Russification of the non-Russian peoples.

Modern researches show a keen theoretical and practical interest in studying the educational, missionary, scientific and social activity of Mashanov M.A., who was a lecturer of the missionary anti-Muslim department of the Kazan Theological Academy. They are also concerned with the analysis of his scientific works on the history, ethnography, language and culture of the Turkic and Finno-Ugric nations of the Middle Volga region and Cisural area in Kazan. Being an Islamic sciences scholar, an expert of the Arabic language, a public figure, the chairman of the Translation Committee, the editor of the magazines "Tserkovno-obschestvennaya zhizn" ("The Church and Social Life") and "Inorodcheskoye obozrenie" ("Non-Russian Review"), Mashanov M.A. made an outstanding contribution to the education of baptized Tatars, Chuvash, Maris, Udmurts, Mordvins, etc. His biography is closely connected with the Kazan Theological Academy and the orthodox missionary organization "The Brotherhood of St. Gurias". The research is based on new archival materials and sources which allowed the authors to give a comprehensive assessment of the problem.

\section{Methodological Framework}

This research uses modern principles and ideas of worldview, gnosiology and logics that play an important role in investigating the events, stages and directions of the development of the missionary anti-Muslim department of the Kazan Theological Academy, Mashanov's researches on the history, ethnography, language and culture of the Turkic and Finno-Ugric peoples of the Middle Volga region and Cisural area in Kazan in the second half of $19^{\text {th }}$ and at the beginning of the $20^{\text {th }}$ centuries.

The methodology of the research draws on general scientific methodological principles and methods applied in modern historical science. The following principles of historical knowledge formed the basis of the research:

- the principle of historicism that implies examining any historical phenomenon in its development, revealing both specific features of each phenomenon and the factors causing it;

- the principle of integrity that requires considering the examination of each phenomenon as the system of interrelated elements and reasons indicating them.

The methods of system-oriented and complex analysis allowed us to provide a complete picture of the formation of Mashanov's outlook, his development as a scientist and a missionary, to learn the facts of his biography and also to analyze his works. Taking into account the specific nature of the research topic we used the statistical and sociological methods as well.

While dealing with the history of the region's people, the integrated approach was applied that involved knowledge of different scientific fields and disciplines, their synthesis and adaptation to the subject matter of the given research, that is, the indication of the character of the interconnection of geographical, economic, socio-historical, national and cultural factors.

The use of the ethno-genetic approach made it possible to define the nature of relationships of ethnic groups; to learn "people-nature" relations within particular ethnic communities; to consider the solution of ethnic problems based on respect for the history of the people, their spiritual values and national consciousness.

\section{Results and Discussions}

Recently, the issues of interfaith dialogue and interethnic relations have gained a great importance in Russia. The questions of developing the professional competence in interfaith and interethnic conflict resolution have come to the fore. Studies of the history, ethnography, cultural heritage and languages of nations and ethnic groups of Russia acquire theoretical and practical significance. The attention of scientists and politicians is increasingly attracted to the history and ethnography problems, processes of the cultural development of Russia in pre-revolutionary and Soviet times. In this case, reference to the experience of a major scientific and educational center of Russia - the Kazan Theological Academy - is of great value. It was natural, as in the second part of the $19^{\text {th }}$ and at the beginning of the $20^{\text {th }}$ centuries it was the place where scientific researches on the history, ethnography, culture and languages of the Finno-Ugric, Turkic, and Mongolian peoples of the Volga, Cisural and Siberian areas were held. The lecturers of the only Russian missionary institutes professionally studied the history and doctrines of Christianity, Islam, Buddhism, pagan religions of nations and ethnic groups. It has to be mentioned that here the examination of the religious systems and languages of the non-Russians acquired a 
number of characteristics, which were typical for the missionary-oriented "Kazan school". While accomplishing the state order to carry out a large-scale missionary policy based on the Russian language and orthodoxy, the lecturers and graduates of the Academy managed to come up with their own methods and ways of investigation, created interesting works on History and Ethnography.

The analysis of the cultural heritage of the lecturers of the missionary departments of the Kazan Theological Academy represented by abundant scientific works on History and studies of Islam, the culture, ethnography, and languages of the Finno-Ugric, Turkic and Mongolian nations in Russia as well as the state of orthodox missionary activities in the Muslim countries of the Middle East, has become an issue of current concern nowadays. In the second part of the $19^{\text {th }}$ and at the beginning of the $20^{\text {th }}$ centuries, the Kazan Theological Academy was a major scientific and educational center of the Volga region, Cisural area and Siberia. It became the center of maintaining a large-scale missionary policy in the eastern part of Russia, the place where N.I. Ilminsky's educational system for the non-Russians was created; Christianization and Russification of non-Russian nations of the Russian State were achieved; events related to the integration of nations and ethnic groups into a single information, educational and cultural space based on the Russian language and orthodox Christianity were held.

History of world religions and pagan religions of the nations of Russia were widely studied in the Kazan Theological Academy. It should be pointed out, that here the studies of Islam, Buddhism, the religious beliefs and languages of the Finno-Ugric, Turkic, and Mongolian peoples have acquired a number of characteristics, which were typical for the missionary-oriented "Kazan school"; their own techniques and methods of investigation were developed; new ideas were practically implemented and a whole range of talented scientists appeared such as Ilminskiy N.I. (1887), Malov E.A. (1891), Ostroumov N.P. (1876), Mashanov M.A. (1881), Zhuze P.K. (1899), Koblov J.D. (1916) and others. They were involved in the activity of the Russian missionary institutes which were part of the Kazan Theological Academy in the years between 1854 and1920. As it was noted by a Russian Islamic studies scholar, a professor of the University of Cologne Mark Batunsky, the students and lecturers of the anti-Islamic department of the Kazan Theological Academy "....were the first Russian professional missionaries and Islamic studies scholars" (Batunsky, 1987).

A huge pile of scientific information, gathered by students, graduates and lecturers of the missionary institutes during the years of 1854 and 1920 up to the present, consists of manuscripts and is held in the archives of Russia. However, in the last decades a serious breakthrough has been reached in studies of the history of pre-revolutionary theological institutions, the activity of their lecturers, and their contribution to the national science. Particularly, the history of the Kazan Theological Academy was studied by Russian and foreign scientists -Zhuravskiy A.V. (1999), Geraci R. (2001), Valeev R.M. (1998; 2009), Khabibullin M.Z. (2013), etc.

The analysis of the works and scientific heritage of a bright representative of the Kazan oriental studies school of the second half of the $19^{\text {th }}$ and the beginning of the $20^{\text {th }}$ centuries, Mashanov M.A., is of great scientific and practical interest. Being an orientalist, an Islamic studies scholar, an expert of the Arabic language, a professor of the Kazan Theological Academy, a social activist, the chairman of the Translation Committee, the editor of the magazines "Tserkovno-obschestvennaya zhizn" and "Inorodcheskoye obozrenie", the author of works on the history of Islam, culture, ethnography and languages of the Finno-Ugric and Turkic peoples in pre-revolutionary Russia, Mashanov M.A. made a significant contribution to the education of baptized Tatars, Chuvash, Maris, and others. His biography is closely connected with the Kazan Theological Academy and the orthodox missionary organization "The Brotherhood of St. Gurias". The research is based on new archival materials and sources which allowed the authors to give a comprehensive assessment of the problem.

The name of Mashanov M.A. is not widely known among modern history researchers, to say nothing of the general public. Yet, Mashanov M.A. is the author of interesting works on the history, ethnography and culture of the Finno-Ugric and Turkic peoples of the Middle Volga region and Cisural area, Middle East countries, the history and doctrine of Islam, etc. (Mashanov, 1875; Mashanov, 1885; Mashanov, 1889). The scientist achieved notable results in the studies of religious and moral state of the Tatars, Chuvash, Maris, Kirghiz and Kazakhs; paid much attention to the analysis of linguistic peculiarities of the languages of nations inhabiting the Volga, Cisural and Middle East regions. In his works, the researcher examined the factors of the development and functioning of Islam within the borders of Russia, indicated Muslim movements which were spread in the area, distinguished the problems of this religion's influence on the traditions, customs and lifestyle of the nations, who converted to Islam, investigated the most significant milestones in the life and activity of the Prophet Mohammed, studied ancient Arabic history, the essence of the Muslim marriage, theological law schools in Islam, and others. Intending to learn the basics of Islam, the scientist examined the regional peculiarities of the culture of Muslim nations. Mashanov M.A. had profound knowledge of the Arabic language and its grammar, 
several Western European and Turkic languages, knew the most important Muslim sources and literature, was keen on the history and essence of Christianity and Islam as doctrines, which let him speak in religious terms and master the corresponding terminology. He made a notable contribution to the development of Islamic and Arabic studies in Kazan in the second part of the $19^{\text {th }}$ and at the beginning of the $20^{\text {th }}$ centuries.

Mashanov M.A. was born on May 11, 1852, in the town of Petropavlovsk, Tobolsk province (nowadays part of Kazakhstan) in the family of hereditary priests. In 1872 he finished Tobolsk Theological Seminary, in 1876 he became a graduate of the Ecclesiopractical department of the Kazan Theological Academy. During studies in the Kazan Theological Academy Ostroumov N.P. and Timofeev V.T. taught him "missionary subjects against Islam" (renunciation of Islam, the life of Mohammed, the Arabic and Tatar languages), which had been excluded from the obligatory academic curriculum by the Regulations of theological academies in 1869 along with missionary institutes. During the years of 1874 and1876, Mashanov was giving lectures on "brief explanation of the Christianity with comments on the drawbacks of Islam" in Kazan central school for baptized Tatars, which became the first orthodox educational institution for children of Turkic and Finno-Ugric nations in the Middle Volga region.

After graduating from the Academy, Mashanov was appointed the assistant of the inspector of the Kazan Theological Academy, in 1877 - the privat-docent at the department of missionary anti-Islamic subjects (since 1885 - associate professor, 1887 - extraordinary professor, from 1906 - distinguished extraordinary professor, in 1911-1920 - supernumerary professor).

In October 1878, at the general meeting of the orthodox missionary organization "The Brotherhood of St. Gurias" Mashanov was elected a member of the Council of "The Brotherhood of St. Gurias" and its record clerk (from 1899 up to 1914 he was its secretary, not counting the periods of 1885-1886 and 1904-1906) (Mashanov, 1892). The orthodox missionary organization "The Brotherhood of St. Gurias" was one of the central institutions that carried out an extensive missionary policy in Russia among the Finno-Ugric and Turkic peoples of the Middle Volga and Cisural areas. Its activity in the sphere of education had a major impact on the process of educating baptized Tatars, Maris, Chuvash, Mordvins, Udmurts, and others, promoted primary education, laid the ground for the system of national education in the Volga region, contributed to the formation of the national intelligentzia, the establishment of the orthodox non-Russian clergy and the spreading of orthodoxy. Mashanov played a great role in developing this organization, managing the education of the Turkic and Finno-Ugric peoples of the Middle Volga and Cisural areas. In relation to the organizational activity, he went on missions around the entire Kazan province, whose main aim was the propaganda of Christianity, the weakening of Islam's influence and interviews with those who had fallen out of Orthodoxy. He was also in charge of inspecting the activity of the schools of "The Brotherhood of St. Gurias" and explore the drawbacks in the educational process. Mashanov M.A. was one of the organizers of special short-term training courses for teachers of "The Brotherhood". Due to his untiring activity, some results were achieved in recruiting and strengthening religious beliefs among baptized Tatars, Chuvash and Maris.

"The Brotherhood of St. Gurias" had a vital role in the state policy of converting large amounts of the non-Russian population to Christianity. It is pointed out by Livshits M.A.: "Active Russification of the Volga region was carried out by "The Brotherhood of St. Gurias" (Livshits, 1961; Livshits, 1980). Ivanovskiy N.I. claims that "a distinctive feature of "The Brotherhood's" activity in achieving the aim of uniting non-Russian nations with Russians was that the process of uniting was supposed to start in relation with the beliefs of non-Russian peoples, not with the language; with the church, not nationhood, as it was usually done in Western parts. The outstanding leaders of "The Brotherhood" were strongly convinced that if a Muslim or a Pagan Cheremiss turns into an Orthodox Christian, not only in name but also in heart and soul, then they would already be full Russians and no longer than in one or two generations will lose their ethnic identity, at least, according to the state interest and state order" (Ivanovskiy, 1893). Thus, "The Brotherhood of St. Gurias" was chiefly established as a missionary, educational institution. Mashanov worked in this organization up to the year of 1915.

Mashanov M.A. paid a special attention to the studying of the Middle East countries. It was the issue of great concern in the $19^{\text {th }}$ century and still is in modern times. In 1885, he presented a thesis for a degree of Doctor of historic sciences under the title "An outline of the Arabic daily life in the era of Mohammed as an introduction to Islam studies". In October of the same year, the Council of the Kazan Theological Academy sends him to the Middle East - to Syria, Palestine, Egypt and Arabia - to study the Arabic language and theological literature. His travel resulted in such works as "European Christians in the Muslim East" (Mashanov, 1889), "The Description of the Journey around the East" (Mashanov, 1887), and others, which provide interesting facts about the life in the Middle East and its inhabitants in the $19^{\text {th }}$ century. 
The mission trip to the Muslim East, the examination of the doctrine of Islam, history and modern life of the Arabs, their language, religious sources and literature, had a great impact on shaping Mashanov's objective scientific views on the Muslim religion and Muslim nations. The acquaintance with the daily routine of the local people and Europeans made an inexpiable onerous impression on him. In his works about the East, Mashanov M.A. reveals the sad conditions, which according to his opinion, established there due to the visitors' fault, not due to the fault of Islam and its disciples. He assumes that moral depravation, immorality, cruelty and deceitfulness of Europeans became the main reason for Muslims' hostility towards all Christians. The European civilization, he thought, had only disturbed the quiet Eastern life and brought the elements of strife, depravity and chaos to it. In the East, Mashanov understood that those were Europeans, who resembled barbarians by their behaviour and attitude, permanently doing evil, while Muslims were an example of high morals, good nature and hospitality. He points out that the wrath of Muslims against Europeans was just a defence reaction to callousness of the first and to arrogance or violence of the last. Therefore, Islam with its appeal for jihad played by no means the key role in the negative attitude of the local eastern population towards foreigners.

Based on the reports Mashanov managed to acquire significant knowledge about Islam. A prominent Soviet orientalist Krachkovskiy I.Y. wrote about the good influence of the trip to the Middle East on Mashanov: "It allowed him to get acquainted not only with the Arabic language, but also with the whole Muslim world, various representatives of which he could meet in Hejaz. Due to this fact, his report on the trip is of great interest." (Krachkovskiy, 1950)

Mashanov came back to Kazan in October, 1887. In 1889-1916, he ran lectures on theological encyclopedia, history and "denunciation of Mohammedan", and the Arabic language in two-year missionary courses, which were started on the basis of the Kazan Theological Academy in 1889.

In 1892 Mashanov was appointed the treasurer and the manager of the Committee's edition "Missionary anti-Muslim collection", a periodic press organ of the Kazan Theological Academy, which printed works on the History of Islam, Christianity, the ethnography and culture of the Finno-Ugric and Turkic peoples of Russia. In the same year, at the meeting of the Council of the Brotherhood of St. Gurias, Mashanov M.A. was elected the chairman of the Translation Committee which was in charge of translating and editing the books both with "religious and moral" content and of "general and educational character for the baptized non-Russians and Mohammedans" (Nikol'skiy, 1905). The idea of establishing this committee belonged to Ilminskiy N.I. (Ivanov, 1973). The fruits of its work were used widely in all Russia: "The Kazan ... translations spread far outside Kazan, having got a sympathetic welcome everywhere, from Moscow to Irkutsk, from Kazan to Astrakhan steppes" (Ivanovskiy, 1903).

The work of the Translation Committee was aimed at producing the systematic, consecutive interpretations and edition of prayer books and educational literature for the Finno-Ugric, Turkic and Mongolian peoples of the Central Volga region, Cisural area, Siberia and the Far East. During the years of existence, the committee published about two million copies of books in fifteen non-Russian languages and dialects (Kamenev, 1930).

In 1878 Mashanov became a member of "The Society of archeology, history and ethnography" of the Kazan University. In 1905-1907 he worked in the editorial office of the magazine "Tserkovno-obschestvennaya zhizn", in 1912 he was the head of the editorial office of the magazine "Inorodcheskoye obozrenie". The magazines paid much attention to the history and ethnography of the peoples of Russia.

The missionary activity is the key feature of Mashanov's multisided biography. Being an expert in this issue he had to attend quite frequently all-Russian events devoted to the missionary policy and education of the Turkic, Finno-Ugric and Mongolian nations of Russia. In May and June, 1905, in St.-Petersburg Mashanov took part in "The special meeting on the questions of education of the eastern non-Russians" under the chairmanship of the cabinet minister Budilovich A. S. The members of the meeting were to work out the basis for improving the system of elementary school education of the ethnic minorities of East Russia. Specialists in Eastern "non-Russian" education and also experts in Islam and Buddhism were invited to participate in the meeting. Most of the members of the meeting were the followers of Ilminskiy's system (Bobrovnikov N., Ostroumov N., Yakovlev I., etc.) (Gorohov, 1941). Mashanov M.A. made a report headlined "The schools of the Brotherhood of St. Gurias in the present state" (The National Archive of the Republic of Tatarstan, fund 967, inventory 1, case 22, 5 pages), in which he drew attention to the development of the orthodox educational organization, provided statistical data on educational institutions of the Kazan province: "There are 63 baptized Tatar schools, 50Chuvash schools, 20Cheremiss schools, Votyak (18) and Mordovian (1 school) schools". Summing up the results, Mashanov M.A. underlined the fruitful work of the educational institutions, thus, he marked out their "comparatively small quantity". He assumed that 152 schools were unable "to embrace all the districts that needed them". Mashanov 
M.A. called insufficient financing the main reason of such "a small number". He also noted the huge work of teachers who "invited to school parents, relatives of the pupils and other non-Russians and after classes had conversations with them on religious and educational subjects". In his opinion, a teacher had to know the key works on religious education as "it is necessary to acquaint the non-Russians in advance with these books through public reading to excite interest in them". Mashanov M.A. deeply regretted that "the shortage of funding doesn't allow the Brotherhood of St. Gurias to annually run the courses for teachers... so, these courses are held rather seldom" (The National Archive of the Republic of Tatarstan, fund 967, inventory 1, case 22, Pages: 2, 3, 5).

In 1910 Mashanov took part in the Missionary Congress which was held in Kazan on June 13-26. Mashanov made a report on "The current status of Tatar-Mohammedans and their treatment of other people", in which he admitted the force and power of Islam among the Turkic and Finno-Ugric peoples of the Central Volga area. In his report, Mashanov pointed to the strengthening of Islam among the people of Russia at the beginning of the $20^{\text {th }}$ century: "It is common knowledge that Mohammedan propaganda has been spread among the non-Russian peoples of the Volga region for a long time and, undoubtedly, it was to strengthen and it has really strengthened recently due to the declared freedom of faith which is quite often interpreted by the Tatars as the right to propaganda their own faith" (Mashanov, 1910: 3). The author gave the reasons for the wide spreading of Islam, the main of which was the vigorous activity of Muslim Tatars themselves. "An oral sermon ... and vast Tatar-Mohammedan literature, - he wrote, - on the widest scale are applied by Muslims to promote the concepts and beliefs among the non-Russians. The Tatar-Mohammedans have been and are the united mass inspired by the spirit of the zealous propaganda which is so encouraged by the main doctrine of Islam, and they are supported by baptized and pagan non-Russians that provide favorable circumstances for sowing the seeds of any faith at the appropriate conducting of the propaganda" (Mashanov, 1910: 5).

In the years between 1919 and 1920 Mashanov ran the courses in "Islam among the nationalities of East Russia", "History of Islam among the tribes of the Volga region", Islamic studies and taught the Arabic language in the east office of the North-East archaeological and ethnographic institute. The National archive of the Republic of Tatarstan possesses a fundamental unpublished work consisting of 38 volumes of "Islam among the Peoples of East Russia" which was investigated here by the scientist.

On February 9, 1920, Mashanov was awarded the title of Professor in new Soviet setting. On March 18, 1921, among the nineteen professors of the Academy he was arrested by the All-Tatar extraordinary commission on the matters of illegal functioning of the Kazan Theological Academy. The lecturers were released as the commission failed to prove their fault, though each received a year of concentration camps. There are no facts about the further life of the scientist.

In conclusion, we would like to note that Mashanov, being a lecturer of the Kazan Theological Academy, a missionary, an active public figure, an educator of the Finno-Ugric and Turkic peoples of the Central Volga and Cisural areas, made a significant contribution to the research and development of problems of Islam, to the modelling of the confessional educational system, to the studying and preservation of the languages of non-Russian peoples. In his works he considered various aspects of the functioning of Islam, the activity of the prophet Mohammed, the issues of marriage in Islam, the status of woman, the sects, the role and the place of the Arabs in the development of Islam as a religion and other questions. His historiographical reviews about the translations of the Koran and researches on the Arab philosophy in Western Europe attracts a great scientific interest. Mashanov is the author of numerous reports on trips to the Kazan province, Russia and the Arab East (Syria, Arabia, Egypt, etc.). He wrote a large number of works and missionary reports in which he describes the mode of life, traditions and language of the Tatars of the Kazan province in the second part of $19^{\text {th }}$ and at the beginning of the $20^{\text {th }}$ centuries.

\section{Conclusion}

As a scientist, a missionary and a public figure, Mashanov M.A. dealt with important state and national issues, religious questions and relationships of peoples and nationalities, which remain urgent today. The relevance of the research is determined by an increasing interest of governmental institutions and the society in general in the problems of regulating interethnic and interfaith relations, protection of the rights of indigenous ethnic groups and preservation of the national cultural diversity. The integration of extensive territories of the Middle Volga region into the Russian State since the second half of the $16^{\text {th }}$ century became a starting point in the formation of the Russian multi-ethnic and multi-confessional space. Many scientific organizations and societies have turned their attention to studying the people of Russia. In the second half of $19^{\text {th }}$ and at the beginning of the $20^{\text {th }}$ centuries the Kazan Theological Academy was one of the largest Russian scientific and educational centres of the history, culture, ethnography, languages, religious beliefs of the peoples of the Middle Volga area. The 
lecturers of the missionary departments of the Academy (Ilminskiy N.I., Sablukov G.S., Malov E.A., Ostroumov N.P., Mashanov M.A., Timofeev V.T., Zhuze P.K., etc.) found out and collected a huge number of various (historical, linguistic, ethnographic) materials about the Tatars, Maris, Chuvash, Udmurts, Mordvins which are of great importance while investigating the roots of modern international and inter-confessional relations in the Republic of Tatarstan and the Russian Federation.

\section{Recommendations}

The paper findings may be useful for researches that deal with missionary policy and modern ethno-political processes in the Russian Federation as well as while writing a general work on the History of peoples of Russia or giving lectures on the History of Russia and foreign countries.

\section{Acknowledgments}

The work is performed according to the Russian Government Program of Competitive Growth of Kazan Federal University.

\section{References}

Batunsky, M. (1987). Russian missionary literature on Islam. Zeitschrift fur Religions und Geistesgeschichte, 39(3), 261. http://dx.doi.org/10.1163/157007387x00219

Bennigsen, A., \& Lemercier-Quelquejay, C. (1967). Islam in the Soviet Union. New York: Fredrick A. Praeger Publishers.

Dimitriyev, V. D. (2002). Prosvetitel' chuvashskogo naroda I.Ya. Yakovlev. Cheboksary.

Geraci, R. (2001). Window on the East: National and Imperial Identities in Late Tsarist Russia. USA: University of Virginia, 91.

Gorohov, V. M. (1941). Reaktsionnaia shkol'naia politika tsarizma v otnoshenii tatar Povolzhya. Kazan.

Habibullin, M. Z. (2013). Narody Srednego Povolzhya i Priuralya v rakurse etnopoliticheskih i istorikokonfessional'nyh issledovaniy prepodavatelei Kazanskoy duhovnoy akademii (1842-1921 gg.). Kazan.

Ilminskiy, N. I. (1887). Kazanskaia kreschenno-tatarskaia shkola. Materialy dlia istorii prosveschenia. Kazan.

Islayev, F. G. (1999). Provaslavnyie missionery v Povolzhye. Kazan.

Ivanov, S. N. (1973). N.F. Katanov. Ocherk zhizni i deyatel'nosti. (Dissertatsiia doktora istoricheskih nauk). Moskva.

Ivanovskiy, N. I. (1903). Bratstvo Svyatitelia Guriia i harakter yego deyatel'nosti. "Provaslavniy sobesednik". Iyun, 741.

Kamenev, S. A. (1930). Tserkov'i prosveschenie v Rossii. Moskva.

Koblov, Ya. D. (1916). Konfessional'niye shkoly kazanskih tatar. Kazan.

Krachkovskiy, I. Yu. (1950). Ocherki po istorii russkoi arabistiki v SSSR. Moskva, Leningrad, 129

Livshits, M. A. (1961). Religiia i tserkov'v proshlom i nastoyaschem. Minsk, 75.

Livshits, M.A. (1980). Religiia i tserkov'v istorii obschestva. Minsk, 258.

Malov, Ye. A. (1891). O kreschennyh tatarah (iz missionerskogo dnevnika). Kazan.

Mashanov, M. A. (1875). Zametka o religiozno-nravstvennom sostoyanii kreschennyh tatar Kazanskoy gubernii Mamadyshskogo uyezda. Kazan.

Mashanov, M. A. (1881). Otchet o poyezdke v derevnyu Nikiforovo Mamadyshskogo uyezda dlia uveschaniia otpavshih ot hristianstva. 27 oktyabrya 1881 goda (Natsional'niy arhiv Respubliki Tatarstan, fond 967, opis' 1, delo 8, 18 listov).

Mashanov, M. A. (1885). Ocherk byta arabov v epohu Muhammeda, kak vvedenie k izucheniyu islama. Kazan.

Mashanov, M. A. (1887). Opisaniye puteshestviya po Vostoku. Kazan.

Mashanov, M. A. (1889). Yevropeyskiye hristiane na musul'manskom Vostoke. Kazan.

Mashanov, M. A. (1892). Obzor deyatel'nosti Bratstva svyatilelia Guriia za dvadtsat' pyat' let yego suschestvovaniia. 1867-1892 gg. Kazan.

Mashanov, M. A. (1910). Sovremennoye sostoyaniye tatar-muhammedan i ih otnosheniye $k$ drugim inorodtsam. Kazan: 3. 
Natsional'niy arhiv Respubliki Tatarstan, fond 967, opis' 1, delo 22, 5 listov.

Nikol'skiy, N. V. (1905). Perevodcheskaia komissiia v Kazani i yeyo prosvetitel'naya deyatel'nost'sredi inorodtsev. Kazan, 9.

Ostroumov, N. P. (1876). Perviy opyt slovaria narodno-tatarskogo yazyka po vygovoru kreschennyh tatar Kazanskoy gubernii. Kazan.

Otchet o deyatel'nosti Bratstva svyatilelia Guriia za 25 god. 1893. Kazan, 34.

Pipes, R. (1993). Rossiia pri starom rezhime (Russia under the old regime). Per. s angl. M.: Nezavisimaya gazeta.

Taymasov, L. A. (2004). Pravoslavnaia tserkov' i hristianskoye prosveschenie narodov Srednego Povolzhya vo vtoroi polovine XIX-nachale XX veka. Cheboksary.

Valeev, R. M. (1998). Kazanskoye vostokovedenie: Istoki i razvitie (XIX v. - 20-e gg. XX v.). Kazan.

Valeev, R. M. (2009). Rossiyskoye universitetskoye vostokovedenie $v$ arhivnyh dokumentah: tsentry, sobytiia $i$ nasledie (XIX - nach. XX vv.). Kazan.

Werth, P. W. (1997). Subjects for Empire: Orthodox mission and imperial governance in the Volga-Kama region, 1825-1881. USA: University of Michigan.

Zhuravskiy, A. V. (1999). Kazanskaia duhovnaia akademiia na perelome epoh. 1884-1921 gg. (Dissertatsiia kandidata istoricheskih nauk). Moskva.

Zhuze, P. K. (1988). Mutazility. Dogmatiko-istoricheskoye issledovanie v oblasti islama. Kazan.

\section{Copyrights}

Copyright for this article is retained by the author(s), with first publication rights granted to the journal.

This is an open-access article distributed under the terms and conditions of the Creative Commons Attribution license (http://creativecommons.org/licenses/by/3.0/). 